\title{
RELATIONSHIP BETWEEN BODY WEIGHT AND LINEAR BODY DIMENSIONS OF GUINEA PIG (Cavia porcellus) IN THE SOUTHERN GUINEA SAVANNAH ZONE OF NIGERIA
}

\author{
Egena Stephen Sunday Acheneje ${ }^{1 *}$
}

Department of Animal Production, Federal University of Technology, P.M.B. 65, Minna, Niger State, Nigeria. * essa_may25@yahoo.com (Corresponding author)

Received on $18^{\text {th }}$ January 2010, accepted in revised form $15^{\text {th }}$ March 2010.

\begin{abstract}
Data on 24 weaned guinea pigs were used to evaluate the relationship between live body weights and linear measurements. The traits measured were body weight (BW), body length (BL), heart girth (HG), trunk length (TL), fore leg length (FLL), hind leg length (HLL) and ear length (EL). Measurements of body components were regressed against live weight at 4, 6, 8, 10 and 12 weeks using linear, quadratic and exponential regression analyses. The regression equations, estimates of parameters and coefficient of determination $\left(\mathrm{R}^{2}\right)$ for the fitted functions were determined. Strong interrelationships $(\mathrm{p}<0.05)$ were observed among the parameters. The coefficient of determination $\left(\mathrm{R}^{2}\right)$ values varied from 0.00 to $0.42 \%, 0.16$ to $0.78 \%$, 0.10 to $0.81 \%, 0.15$ to $0.80 \%$ and 0.03 to $0.68 \%$ at $4,6,8,10$ and 12 weeks respectively. Body length (BL) had higher $\mathrm{R}^{2}$ value at 4 weeks $(0.42 \%), 6$ weeks $(0.78 \%)$ and 8 weeks $(0.81 \%)$ respectively with the exponential function while; heart girth had higher $\mathrm{R}^{2}$ value at 10 weeks with the exponential function $(0.80 \%)$ and at 12 weeks $(0.68 \%)$ with quadratic function. Based on $\mathrm{R}^{2}$ value, exponential function was generally superior in terms of goodness of fit to the data and its ability to predict body weight.
\end{abstract}

(Keywords : Body length, heart girth, trunk length, fore leg length, hind leg length, ear length)

\section{INTRODUCTION}

The problem of low protein intake in developing countries is a reoccurring issue in many international discourses. That the average intake of protein especially that of animal origin is grossly below Food and Agriculture Organization [FAO] approved standard in these countries is no longer news. That the conventional livestock such as cattle, sheep, goat, pig and poultry are also not able to provide this needed protein in adequate amount is a statement of fact. Hence the drive toward encouraging the rearing and exploitation of lesser known animals such as snail, quail, rabbit and guinea pig as a source of cheap and readily available protein particularly in the rural areas where most of the resource poor people live. Hitherto, the guinea pig had gained popularity as a laboratory animal used in testing new drugs and other pharmaceutical products. Although its contribution to the supply of protein in the diets of many people in developing countries such as Bolivia [1] and Nigeria as well as the Philippines [2] has been largely ignored, it is a veritable source of protein as well as income. Guinea pigs measure between $20-40 \mathrm{~cm} \mathrm{[3]} \mathrm{and} \mathrm{can} \mathrm{attain} \mathrm{adult} \mathrm{weight}$ of between $500-1500 \mathrm{~g}$ [4] with females weighing slightly less than males.
Live body weight and linear body traits are great contributors to the lifetime performance of animals. Studies involving body measurements and weights in poultry [5, 6, 7, 8,], sheep [9], goat [10], cattle $[11,12]$ and rabbit [13, 14] have been reported. Findings from these reports have been used to describe body conformation and carcass composition, evaluate breed performance, predict live weight gain, examine relationships between heredity and economic characteristics, reproductive performance, and study the interaction between heredity and environment and the relationship between body weights and linear body dimensions. Data obtained from such studies has been used as valuable indicators for selection. [10] reported on the importance of using skeletal dimensions such as shoulder width, heart girth and height at withers for predicting live weight and condition score.

There is scarcity of literature on research about the guinea pig in Nigeria and especially those relating linear body measurements to productive traits in the guinea pig. This might be due to inadequate research in the animal since most people do not think of the animal as a good source of meat. Research on the animal has however been carried out in the Cameroon republic $[15,16,17]$. This study therefore was designed to determine the 
existing relationships between body weight and linear body measurements such as body length (BL), heart girth (HG), trunk length (TL), fore leg length (FLL), hind leg length (HLL) and ear length (EL) of guinea pigs as well as attempt to predict live body weight from linear body measurements using linear, quadratic and exponential models.

\section{MATERIALS AND METHODS}

\section{Location of study}

The study was conducted at the Teaching and Research Farm of the Federal University of Technology, Minna, Niger State, Nigeria. Minna is located at latitude $9^{\circ} 31^{\prime}$ and $9^{\circ} 45^{\prime}$ north,

and longitude $6^{\circ} 31^{\prime}$ and $6^{\circ} 45^{\prime}$ east of the equator. It is situated at an altitude of 1475 metres above sea level. It lies within the southern guinea savannah agro-ecological zone of Nigeria. It is characterized by two distinct climate; harmattan (NovemberApril) and rainy (May-October). The annual rainfall and mean temperature range are: $1,100-1300 \mathrm{~mm}$ and $38-42^{\circ} \mathrm{C}$ respectively.

\section{Experimental animals and their management}

The 24 guinea pigs used for the experiment were sourced locally from Kagara, Kotangora and Gwada all within Niger State. The weaned nonpedigreed animals were purchased from peasant farmers who keep them primary for meat. They were housed in hutches made of wood and wire mesh. The wire mesh was placed at the bottom and sides of the hutch. This is to ensure proper ventilation and easy disposal of droppings. The dimension of the hutch was $65 \mathrm{~cm} \mathrm{x} 46.5 \mathrm{~cm} \mathrm{x}$ $58.8 \mathrm{~cm}$. The hutches were raised 30 inches above the floor level. The hutches were large enough to allow for easy movement. Feeders and drinkers were provided. The house and the surroundings were kept clean. The house was swept daily and drinkers also washed regularly. The animals were treated against both internal and external parasites by the use of Ivomec ${ }^{\circledR}$. Anti-stress was provided in the form of Vitalyte ${ }^{\circledR}$.

\section{Feeding and watering}

The guinea pigs were fed ad libitum compounded diet supplemented with Tridax procumbens and Mangdifera indica leaves over the course of the experiment. The ingredients used in making the feed included: maize, soya bean, maize bran, methionine, lysine, palm oil, bone meal, premix and salt. Clean water was given ad libitum.

\section{Data collection}

Collection of data started 4 weeks after the commencement of the experiment and thereafter at two weekly intervals until the $12^{\text {th }}$ week. The linear body traits studied were body length (BL), heart girth (HG), trunk length (TL), fore leg length (FLL), hind leg length (HLL) and ear length (EL). Measurements were taken using measuring tape. The linear measurements are as follows:

$\mathrm{BL}=$ length between the tip of the nose and the rump.

$\mathrm{HG}=$ body circumference taken just behind the fore legs.

$\mathrm{TL}=$ length between the neck and the rump.

FLL = length from the point of attachment of the fore leg to the tip of the fore leg.

HLL = length from the point of attachment of the hind leg to the tip of the hind leg.

$\mathrm{EL}=$ length from the point of attachment of the ear to the tip of the ear.

\section{Data analysis}

Data obtained of each of the linear body measurements, BL, HG, TL, FLL, HLL and EL were regressed against live body weight at $4,6,8$, 10 and 12 weeks using both linear, quadratic and exponential regression analyses. The analysis was carried out using [18].

The functions or models used were:

$\begin{aligned} & \mathrm{Y}=\mathrm{a}+\mathrm{bx} \ldots \ldots \ldots \ldots \ldots \ldots \ldots \ldots \ldots \ldots \ldots \ldots \ldots \ldots \ldots \ldots \ldots \ldots \ldots \ldots \ldots \ldots \ldots\end{aligned}$ quadratic or polynomial.

$$
\mathrm{Y}_{2}=\text { aiebx }
$$

exponential.

Logarithm transformation was done to fit the exponential model with the variable data resulting in the equation;

$\log 10 \mathrm{Y}_{2}=\log 10 \mathrm{ai}+\mathrm{bx}$

Where $\mathrm{Y}, \mathrm{Y}_{1}$, and $\mathrm{Y}_{2}=$ dependent variables (live weight). $\mathrm{x}=$ independent variables $(\mathrm{BL}, \mathrm{HG}$, TL, FLL, HLL, El).

b, $\mathrm{c}=$ regression coefficient associated with the independent variables.

The relationship between live weight and each of the linear body measurements was accessed. The coefficient of determination $\left(\mathrm{R}^{2}\right)$ was used to compare the accuracy of prediction.

\section{RESULTS}

Table 1 represents equations, estimates of parameters and coefficient of determination $\left(R^{2}\right)$ for the fitted functions at 4 weeks. Linear body measurements and weight had mostly significant $(p<0.05)$ association which goes to show the strong interrelationship between body weight and the linear measurements. The value of $\mathrm{R}^{2}$ ranged from 0.20 to 43.2 being maximal for body length using exponential function. Majority of the regression coefficients were positive. A comparism on the basis of $\mathrm{R}^{2}$ values showed that weights and linear body measurements were best fitted by the exponential function followed by the quadratic 
function and linear function. There was only one case where no significant $(\mathrm{p}>0.05)$ relationship existed between weights and linear dimensions (HLL using linear function). Quadratic and exponential equations could not be generated for FLL because the data could not fit.

Table 2 represents equations, estimates of parameters and $\mathrm{R}^{2}$ for the fitted functions at 6 week. Linear body dimensions associated significantly $(\mathrm{p}<0.05) \quad$ with weight showing strong interrelationship. Except for FLL where data could not fit for exponential function, all the relationships were significant $(\mathrm{p}<0.05)$. Based on $\mathrm{R}^{2}$ values, weights and linear body measurements were best fitted by the exponential function except for $\mathrm{HG}$ and TL where the quadratic function performed better.

Table 3 represents equations, estimates of parameters and $\mathrm{R}^{2}$ for the fitted functions at 8 weeks. Linear body measurements associated significantly $(\mathrm{p}<0.05)$ with weights. A comparism of $\mathrm{R}^{2}$ values showed that weight and linear body measurements were best fitted by the exponential function except for FLL where quadratic function was better. The trend was similar at week 10 (Table 4) except for body length where the quadratic function fitted the data best.

Table 5 represents equations, estimates of parameters and $\mathrm{R}^{2}$ values for the fitted functions at 12 weeks. While most of the linear body measurements and weights had significant $(p<0.05)$ and strong interrelationship between them, some were not significant (EL using all the functions).

The $\mathrm{R}^{2}$ values ranged from 0.03 to 0.68 . Quadratic function better fitted the data for BL, HG TL and FLL while the exponential function better fitted the data for HLL and EL. Generally, among the linear body measurements, accuracy of prediction was better with BL $\left(\mathrm{R}^{2} 0.77,0.78,0.81\right.$ in Table 3$), \mathrm{HG}$ $\left(\mathrm{R}^{2}\right.$ 0.73, 0.78, 0.80 in Table 4), BL $\left(\mathrm{R}^{2}\right.$ 0.76, 0.77, 0.76 in Table 4$)$, EL $\left(\mathrm{R}^{2} 0.72,0.73,0.76\right.$ in Table 3$)$ and HG $\left(\mathrm{R}^{2} 0.54,0.71,0.76\right.$ in Table 3$)$. It would appear as if $\mathrm{BL}$ and $\mathrm{HG}$ are better predictors of live weight in the guinea pig.

Table 1. Estimation of parameters in linear, quadratic and exponential functions fitted for weight-linear measurement relationship at 4 weeks

\begin{tabular}{|c|c|c|c|c|}
\hline Linear measurement & Function & $\overline{\mathrm{SE}}$ & $\mathrm{R}^{2}$ & Significance \\
\hline \multirow[t]{3}{*}{ Body length } & $Y=-203+21.37 x$ & 11.0 & 0.32 & $*$ \\
\hline & $Y_{1}=-2336+209 x-412 x^{2}$ & 10.9 & 0.37 & $*$ \\
\hline & $Y_{2}=259-593 x+454 x^{2}-115 x^{3}$ & 0.02 & 0.42 & * \\
\hline \multirow[t]{3}{*}{ Heart girth } & $Y=0.20+19.3 x$ & 11.6 & 0.24 & $*$ \\
\hline & $Y_{1}=-924+142.9 x-4.09 x^{2}$ & 11.7 & 0.27 & $*$ \\
\hline & $Y_{2}=-35.9+88.3 x-67.8 x^{2}+17.4 x^{3}$ & 0.02 & 0.31 & * \\
\hline \multirow[t]{3}{*}{ Trunk length } & $Y=219+14.6 x$ & 13.1 & 0.04 & * \\
\hline & $Y_{1}=737-213 x+24.4 x^{2}$ & 12.9 & 0.12 & $*$ \\
\hline & $Y_{2}=-3.37+30.6 x-52.6 x^{2}+29.6 x^{3}$ & 0.02 & 0.15 & * \\
\hline \multirow[t]{3}{*}{ Fore leg length } & $Y=68.9+101 x$ & 12.2 & 0.17 & * \\
\hline & $Y_{1}=$ na & na & na & na \\
\hline & $\mathrm{Y}_{2}=\mathrm{na}$ & na & na & na \\
\hline \multirow[t]{3}{*}{ Hind leg length } & $\mathrm{Y}=323-8.05 \mathrm{x}$ & 13.4 & 0.00 & ns \\
\hline & $Y_{1}=215-867 x+100 x^{2}$ & 13.3 & 0.06 & $*$ \\
\hline & $Y_{2}=64.5-292 x+458 x^{2}-238 x^{3}$ & 0.02 & 0.11 & $*$ \\
\hline \multirow[t]{3}{*}{ Ear length } & $Y=77.6+97.9 x$ & 11.9 & 0.20 & $*$ \\
\hline & $Y_{1}=-26.8+196 x-23.0 x^{2}$ & 12.2 & 0.21 & $*$ \\
\hline & $Y_{2}=-2.58+55.5 x-196 x^{2}+223 x^{3}$ & 0.02 & 0.25 & $*$ \\
\hline
\end{tabular}

* Significant difference $(\mathrm{p}<0.05)$

$\mathrm{ns}=$ not significant $(\mathrm{p}>0.05)$

na $=$ data could not fit the functions

$\mathrm{SE}=$ standard error 
Table 2. Estimation of parameters in linear, quadratic and exponential functions fitted for weight-linear measurement relationship at 6 weeks

\begin{tabular}{|c|c|c|c|c|}
\hline Linear measurement & Function & SE & $\mathrm{R}^{2}$ & Significance \\
\hline \multirow[t]{3}{*}{ Body length } & $Y=-236+24.2 x$ & 10.4 & 0.43 & $*$ \\
\hline & $Y_{1}=-816+73.8 x-1.06 x^{2}$ & 10.6 & 0.43 & $*$ \\
\hline & $Y_{2}=250-549 x+401 x^{2}-978 x^{3}$ & 0.01 & 0.78 & $*$ \\
\hline \multirow[t]{3}{*}{ Heart girth } & $Y=-54.8+25.6 x$ & 10.5 & 0.41 & $*$ \\
\hline & $Y_{1}=122-140 x-5.37 x^{2}$ & 10.2 & 0.48 & $*$ \\
\hline & $Y_{2}=83.0-198 x+162 x^{2}-43.8 x^{3}$ & 0.01 & 0.45 & $*$ \\
\hline \multirow[t]{3}{*}{ Trunk length } & $Y=-33.9+75.3 x$ & 9.03 & 0.57 & $*$ \\
\hline & $Y_{1}=718-232 x+31.1 x^{2}$ & 8.73 & 0.61 & $*$ \\
\hline & $Y_{2}=-19.6+98.2 x-146 x^{2}+73.0 x^{3}$ & 0.01 & 0.56 & $*$ \\
\hline \multirow[t]{3}{*}{ Fore leg length } & $Y=6.90+152 x$ & 11.0 & 0.35 & $*$ \\
\hline & $Y_{1}=-555+516 x-111 x^{2}$ & 10.9 & 0.40 & $*$ \\
\hline & $\mathrm{Y}_{2}=\mathrm{na}$ & na & na & na \\
\hline \multirow[t]{3}{*}{ Hind leg length } & $Y=25.6+754 x$ & 12.6 & 0.16 & $\mathrm{~ns}$ \\
\hline & $Y_{1}=-815+472 x+46.5 x^{2}$ & 12.8 & 0.17 & $*$ \\
\hline & $Y_{2}=-22.5+104 x-219 x^{2}+115 x^{3}$ & 0.02 & 0.19 & $*$ \\
\hline \multirow[t]{3}{*}{ Ear length } & $Y=-29.2+168 x$ & 9.57 & 0.51 & $*$ \\
\hline & $Y_{1}=108-861 x_{+} 236 x^{2}$ & 9.06 & 0.59 & $*$ \\
\hline & $Y_{2}=7.62-59.8 x+172 x^{2}-180 x^{3}$ & 0.01 & 0.63 & $*$ \\
\hline
\end{tabular}

* Significant difference $(\mathrm{p}<0.05)$

na $=$ data could not fit the functions

$\mathrm{SE}=$ standard error

Table 3. Estimation of parameters in linear, quadratic and exponential functions fitted for weight-linear measurement relationship at 8 weeks

\begin{tabular}{|c|c|c|c|c|}
\hline Linear measurement & Function & SE & $\mathrm{R}^{2}$ & Significance \\
\hline \multirow[t]{3}{*}{ Body length } & $Y=-428+33.7 x$ & 6.14 & 0.77 & $*$ \\
\hline & $Y_{1}=-151+122 x-1.82 x^{2}$ & 6.23 & 0.78 & $*$ \\
\hline & $Y_{2}=100-218 x+158 x^{2}-381 x^{3}$ & 0.01 & 0.81 & $*$ \\
\hline \multirow[t]{3}{*}{ Heart girth } & $Y=-110+31.4 x$ & 8.79 & 0.54 & $*$ \\
\hline & $Y_{1}=188-226 x+8.38 x^{2}$ & 7.10 & 0.71 & $*$ \\
\hline & $Y_{2}=262-655 x+547 x^{2}-152 x^{3}$ & 0.01 & 0.76 & $*$ \\
\hline \multirow[t]{3}{*}{ Trunk length } & $Y=39.8+71.2 x$ & 8.19 & 0.60 & $*$ \\
\hline & $Y_{1}=679-190 x+26.3 x^{2}$ & 8.05 & 0.63 & $*$ \\
\hline & $Y_{2}=-41.8+194 x-284 x^{2}+138 x^{3}$ & 0.01 & 0.67 & * \\
\hline \multirow[t]{3}{*}{ Fore leg length } & $Y=39.8+159 x$ & 10.2 & 0.38 & $*$ \\
\hline & $Y_{1}=271-223 x+298 x^{2}-261 x^{3}$ & 10.0 & 0.43 & $*$ \\
\hline & $Y_{2}=15.1-105 x+289 x^{2}-261 x^{3}$ & 0.01 & 0.42 & $*$ \\
\hline \multirow[t]{3}{*}{ Hind leg length } & $Y=156+57.3 x$ & 12.2 & 0.10 & $*$ \\
\hline & $Y_{1}=-99+84.6 x-3.21 x^{2}$ & 12.6 & 0.10 & $*$ \\
\hline & $Y_{2}=-25.5+135 x-217 x^{2}+116 x^{3}$ & 0.01 & 0.13 & $*$ \\
\hline \multirow[t]{3}{*}{ Ear length } & $Y=-106+222 x$ & 6.89 & 0.72 & $*$ \\
\hline & $Y_{1}=-144+141 x-263 x^{2}$ & 6.91 & 0.73 & $*$ \\
\hline & $Y_{2}=43.3-360 x+105 x^{2}-102 x^{3}$ & 0.01 & 0.76 & $*$ \\
\hline
\end{tabular}

* Significant difference $(\mathrm{p}<0.05)$

$\mathrm{SE}=$ standard error 
Table 4. Estimation of parameters in linear, quadratic and exponential functions fitted for weight-linear measurement relationship at 10 weeks

\begin{tabular}{|c|c|c|c|c|}
\hline Linear measurement & Function & SE & $\mathrm{R}^{2}$ & Significance \\
\hline \multirow[t]{3}{*}{ Body length } & $\mathrm{Y}=-408+33.9 \mathrm{x}$ & 5.79 & 0.76 & $*$ \\
\hline & $Y_{1}=116-94.2 x-2.60 x^{2}$ & 5.82 & 0.77 & $*$ \\
\hline & $Y_{2}=-309+677 x-492 x^{2}-119 x^{3}$ & 0.01 & 0.76 & * \\
\hline \multirow[t]{3}{*}{ Heart girth } & $Y=-239+40.9 x$ & 6.09 & 0.73 & $*$ \\
\hline & $Y_{1}=205-243 x+880 x^{2}$ & 5.70 & 0.78 & * \\
\hline & $Y_{2}=555-137 x+112 x^{2}-307 x^{3}$ & 0.01 & 0.80 & $*$ \\
\hline \multirow[t]{3}{*}{ Trunk length } & $Y=121+59.9 x$ & 8.53 & 0.47 & $*$ \\
\hline & $Y_{1}=845-243 x+29.6 x^{2}$ & 8.32 & 0.52 & $*$ \\
\hline & $Y_{2}=-34.5+164 x-240 x^{2}+117 x^{3}$ & 0.01 & 0.57 & * \\
\hline \multirow[t]{3}{*}{ Fore leg length } & $Y=184+103 x$ & 10.8 & 0.15 & * \\
\hline & $Y_{1}=456-379 x+857 x^{2}$ & 10.2 & 0.28 & $*$ \\
\hline & $Y_{2}=31.3-242 x+676 x^{2}-623 x^{3}$ & 0.01 & 0.30 & * \\
\hline \multirow[t]{3}{*}{ Hind leg length } & $Y=104+74.8 x$ & 10.5 & 0.20 & * \\
\hline & $Y_{1}=-464+344 x-31.9 x^{2}$ & 10.7 & 0.45 & $*$ \\
\hline & $Y_{2}=10.6-41.5 x+70.3 x^{2}-38.8 x^{3}$ & 0.01 & 0.45 & $*$ \\
\hline \multirow[t]{3}{*}{ Ear length } & $Y=9.0+177 x$ & 8.72 & 0.45 & * \\
\hline & $Y_{1}=768-499 x+149 x^{2}$ & 8.92 & 0.45 & * \\
\hline & $Y_{2}=-27.9+266 x-771 x^{2}+742 x^{3}$ & 0.01 & 0.51 & $*$ \\
\hline
\end{tabular}

* Significant difference $(\mathrm{p}<0.05)$

$\mathrm{SE}=$ standard error

Table 5. Estimation of parameters in linear, quadratic and exponential functions fitted for weight-linear measurement relationship at 12 weeks

\begin{tabular}{|c|c|c|c|c|}
\hline Linear measurement & Function & SE & $\mathrm{R}^{2}$ & Significance \\
\hline \multirow[t]{3}{*}{ Body length } & $Y=-218+26.3 x$ & 8.58 & 0.37 & $*$ \\
\hline & $Y_{1}=624-485 x+10.1 x^{2}$ & 8.01 & 0.48 & $*$ \\
\hline & $Y_{2}=-185+401 x-289 x^{2}+695 x^{3}$ & 0.01 & 0.46 & $*$ \\
\hline \multirow[t]{3}{*}{ Heart girth } & $Y=-261+41.8 x$ & 7.87 & 0.47 & $*$ \\
\hline & $Y_{1}=656-770 x+24.1 x^{2}$ & 6.33 & 0.68 & $*$ \\
\hline & $Y_{2}=678-162 x+129 x^{2}-342 x^{3}$ & 0.01 & 0.66 & $*$ \\
\hline \multirow[t]{3}{*}{ Trunk length } & $Y=113+62.6 x$ & 8.59 & 0.37 & $*$ \\
\hline & $Y_{1}=109-309 x+35 \cdot 2 x^{2}$ & 8.56 & 0.41 & $*$ \\
\hline & $Y_{2}=-21.9+104 x-149 x^{2}+71.6 x^{3}$ & 0.01 & 0.39 & $*$ \\
\hline \multirow[t]{3}{*}{ Fore leg length } & $Y=-32.8+191 x$ & 10.1 & 0.13 & $*$ \\
\hline & $Y_{1}=-976+933 x-145 x^{2}$ & 10.4 & 0.13 & $*$ \\
\hline & $\mathrm{Y}_{2}=\mathrm{na}$ & na & na & na \\
\hline \multirow[t]{3}{*}{ Hind leg length } & $Y=-84.9+116 x$ & 8.85 & 0.33 & $*$ \\
\hline & $Y_{1}=428-106 x+24.0 x^{2}$ & 9.06 & 0.34 & $*$ \\
\hline & $Y_{2}=362-165 x+254 x^{2}-130 x^{3}$ & 0.01 & 0.42 & $*$ \\
\hline \multirow[t]{3}{*}{ Ear length } & $Y=382+26.2 x$ & 10.6 & 0.02 & $\mathrm{~ns}$ \\
\hline & $Y_{1}=-83.0+388 x-70.1 x^{2}$ & 10.8 & 0.03 & ns \\
\hline & $Y_{2}=0.56+15.2 x-36.7 x^{2}+29.4 x^{3}$ & 0.01 & 0.03 & ns \\
\hline
\end{tabular}

* Significant difference $(\mathrm{p}<0.05)$

$\mathrm{ns}=$ not significant $(\mathrm{p}>0.05)$

na $=$ data could not fit the functions

$\mathrm{SE}=$ standard error 


\section{DISCUSSION}

From the results obtained from the study, it is evident that the linear quadratic and exponential functions could be used in describing relationships between body weights and linear body measurements in the guinea pig. Both the quadratic and exponential models had advantage over the linear model in respect to their goodness of fit to the data. Chineke [13] had reported the simple quadratic model to be superior to both linear and exponential models while evaluating the relationship among body weight and linear dimensions in rabbit breed and crosses. The fact that both the quadratic and exponential models were better compared to the linear model as demonstrated by their coefficients of determination $\left(\mathrm{R}^{2}\right)$ is an indication that live body weight could be better predicted with the use or two or more independent variables. Bemji and Osinowo [19] reported similar finding while predicting milk yield from udder circumference and distance between teats in West African Dwarf and Red Sokoto goats. The best result was obtained in the study with BL at 8 weeks where the highest $\mathrm{R}^{2}$ accounted for $81.0 \%$ of the variation in body weight.

Most of the regression equations generated showed positive values. This is an indication that the parameters were directly influenced by body weight changes. Therefore, gain in weight increases with increase in linear body dimensions [13]. Seale et al. [20], Cason and Ware [21], Orheruata and Olutogun [22] and Omeje et al. [23] all reported similar positive relationships between live body weight and body dimensions in sheep, poultry and cattle. There were few regression coefficients in the relationship between body weight and linear body measurement. This is an indication that the parameters concerned correlated negatively with body weight. Hence as the body weight increases, the linear body measurements concerned decreases. Chineke [13] reported similar finding in rabbit. Dilwali [24] while reporting on observed negative coefficients for regression values in Etah goats concluded that growth rate decreases with increase in age.

\section{CONCLUSION}

Results from the study showed either a negative or positive relationship existing between live body weight and linear body measurements at 4, 6, 8, 10 and 12 weeks of age post-weaning. The result indicate that increase or decrease in the growth rate of any of the linear body measurements correspondingly led to an increase or decrease in live body weight of the animal. The result also revealed the quadratic and exponential models or functions to be best fitted to the data based on the magnitude of the coefficient of determination $\mathrm{R}^{2}$ values.

\section{REFERENCES}

1. Numbela, R. M. and Valencia, C. R. (2003). Guinea pig management manual. Benson Agriculture and Food Institute, Provo UT, USA. 54pp.

2. NRC (1991). Micro-livestock: Littleknown small animals with promising future. National Academy Press, Washington, DC, USA

3. Nowak, R. M. (1999). Cavies, or Guinea pigs. In: Walker's Mammals of the World. $6^{\text {th }}$ ed. Vol. 2. The John Hopkins University Press. Baltimore. Pp: 16671669.

4. Economist (2004). A guinea pig for all tastes and seasons. Accessed using Business Source Complete. $17^{\text {th }}$ July.

5. Auckland, J. N. (1973). Relationships between body weight and bone length at one and six weeks of age in male turkeys fed on adequate and low protein starter diets. British Poultry Science 14: 205-208.

6. Chambers, J. R. and Fortin, A. (1984). Live body and carcass measurements as predictors of chemical composition of carcasses of male broiler chickens. Poultry Science 63: 2187-2196.

7. Monsi, A. (1992). Appraisal of interrelationships among measurements at different ages in meat-type chickens. Nigerian Journal of Animal Production 19: 15-24.

8. Okon, B. I., Oga, B. and Mbere, O. O. (1997). Interrelationships of body weight measurements of broiler chicken in a humid tropical environment. Nigerian Journal of Animal Production 24: 7-12.

9. Chineke, C. A. (1996). Relationship between body measurements and live body weight of Yankasa ewes at various ages. Applied Tropical Agriculture 1: 34-37.

10. Ozoje, M. O. and Mbere, O. O. (2002). Coat pigmentation effects in West African Dwarf goats: live weights and body dimensions. Nigerian Journal of Animal Production 29: 5-10. 
11. Jeffery, H. B. and Berg, R. J. (19720. An evaluation of several measurements of beef cow size as related to progeny performance. Canadian Journal of Animal Science 52: 23-37.

12. McCurley, J. R. and McLean, J. B. (1981). Relationships of body measurements, weight, age and fatness to size and performance in beef cattle. Journal of Animal Science 52: 493-499.

13. Chineke, C. A. (2005). The relationships among body weights and linear dimensions in rabbit breeds and crosses. Journal of Animal and Veterinary Advances 4(9): 775-784.

14. Chineke, C. A., Ikeobi, C. O. N. and Ologun, A. G. (2006). Body measurements of rabbit breeds and crosses at weaning and post-weaning ages. Journal of Biological Science 6(1): 31-37.

15. Ngoupayou, J. D. (1992). Guinea Pig (Cavia porcellus L). Raising for meat production: Research on feeding and monitoring of raising Guinea pigs in villages in Cameroon. In: Microlivestock. Philippines. November 1992.

16. Ngoupayou, J. D., Kouonmenioc, N. J., Tagny, J. M. F., Cicogna, M., Castroville, C., Rigoni, M. and Hardouin, J. (1995). Development opportunities for the guinea pig in sub-Saharan Africa: The case of Cameroon. (In French). Wld. Anim. Rev. 82(2):20-28.

17. Nuwanyakpa, M., Lukefahr, S. D., Gudahl, D. and Ngoupayou, J. D. (1997). The current stage and future prospect of guinea pig production under smallholder condition in West Africa; 1. Global overview. Livestock Research for Rural Development. Volume 9, Article \#5. http://www.lrrd.org/lrrd9/5/gp951.htm

18. MINITAB (2003). Minitab statistical software, release 14 for windows, state college, Pennsylvania, USA.
19. Bemji, M. N. and Osinowo, O. A. (2008). Prediction of milk yield from udder circumference and distance between teats in West African Dwarf and Red Sokoto goats. Nigeria Journal Animal Production 36(1): 1-11.

20. Searle, T. W., McGraham, N. and Donnelly, J. B. (1989). Change of skeletal dimensions during growth in sheep. The effect of nutrition. Journal of Agricultural Science 112: 321-327.

21. Cason, J. A. and Ware, G. O. (1990). Analysis of flock egg production curves using generated growth functions. Poultry Science 69: 1064-1069.

22. Orheruata, A. M. and Olutogun, O. (1994). Pre- and post-weaning phenotypic relationship between some N'dama cattle linear measurements in the tropics. Nigerian Journal of Animal Production 21: 76-82.

23. Omeje, S. I., Alaku, S. O., Odo, B. I. and Emehelu, K. I. (2001). Evaluation of growth performance of calves from different dams mated by the same bull. Nigerian Journal of Animal Production 28: 72-771.

24. Dilwali, C. K. (1948). Analysis of weight records of Etah goats. Indian Journal of Veterinary Science and Animal Husbandry 13: 115-120. 